year professor of the Catholic University at Louvain, which professorship he continued to fill for more than half a century. Van Beneden belonged to a generation of zoologists that connected Cuvier with the present age, and followed so far in this great master's steps, that they worked at almost all the branches of the animal kingdom. If we were to give a summary of the very extensive writings of van Beneden we should begin with his memoirs on apes, seals, whales, and so through the various classes, with perhaps the exception of the birds and reptiles, to the gregarines. Circumstances made him devote a great deal of attention to the groups of parasitic worms and Annelides. Most of his papers on these forms were communicated to the Brussels Academy of Sciences or to the Paris Academy; the latter we find reported on by Quatrefages. He took a leading part in the, at one time, exciting controversy about the "alternation of generations," with the elder Sars, D'Udekem, and others.

Among the more important works of Beneden may be mentioned "The Natural History of the Fresh-water 'Polyzoa," in collaboration with Du Mortier, published in I850, which obtained the Grand Prize of the Paris Academy; the "Zoologie Médicale," in I859, of which Paul Gervais was joint author; the "Recherches sur la Faune Littorale de Belgique" (Polypes), in 1866. In connection with this work it may be mentioned that Beneden's artistic powers were quite remarkable, and that many of his memoirs owe a great deal to his excellent illustrations. A good correspondent, he kept himself acquainted with the work of most of his contemporaries, and he was the writer of many of the short biographical sketches referring to zoologists that appeared from year to year in the Reports of the Brussels Academy. Some of our readers may remember what an active part he took in the Liverpool (1870) meeting of the British Association; Rolleston was president of the biological section, and gave a morning to the discussion of the subject of "commensalism," which at that time Beneden's mind was occupied with, and about which he afterwards (I875) published a volume in the "Bibliothèque Scientifique Internationale," that has been translated into German and English. Peradventure some too may remember how delighted Beneden, with Stricker, Dohrn, and some of the other "foreigners" present at that meeting were, to find that a little nucleus of the great body combined to make the "Association Sunday" as little sad as possible by the practice of a proper commensalism. Full of honour after a long life well and usefully spent, Beneden had the additional reward of seeing his son Edward take a high rank in the modern biological school, in this resembling his great contemporary Henri Milne Edwards. Beneden was a member of very many of the Academies and Societies of Europe, and was an honorary LL.D. of the University of Edinburgh. He died at Louvain on January 8, I 894.

\section{THE GREAT GALE OF NOVEMBER 16-20.}

THE past autumn and early winter were especially due to the very marked a mild and humid atmosphere, winds which have blown with great persistence from the Atlantic. These conditions are without doubt intimately associated with the frequency with which gales have occurred.

The violent storm which was experienced over the entire area of the United Kingdom, as well as over the sea and the parts of the continent adjacent to our islands, from November 16 to 20 , was more severe than the other gales which have recently occurred, and it is necessary

NO. I 265 , vOL. 49] to refer back many years before a storm so violent and so destructive can be found to have traversed the country.

Prior to the advent of the storm an anticyclonic area, with fairly high barometer readings, was situated over our islands, and north-easterly winds were prevalent. On November I4 and I5 a small cyclonic disturbance travelled over the south-western portion of the kingdom, and caused a general giving way in the area of high barometer readings, while the large anticyclone over Europe also materially decreased in its energy. At this time a large cyclonic disturbance was out in the Atlantic, and was rapidly approaching our western coasts ; the first intimation of a renewal of bad weather was shown by a fresh fall of the barometer which set in at Valencia at 4 p.m. I 5 th, and an hour or so later the wind was freshening from the south-east.

On November I 6 the conditions had so far changed that at eight o'clock in the morning the weather chart prepared by the Meteorological Office gave unmistakable indications of an important disturbance at no great distance from the Irish coast, and the Official Weather Report has the following remark :- "A large depression is approaching our western coasts from the south-westward, and is likely to cause rough wet weather over the kingdom generally, especially in the west and north." At this time a strong south-easterly wind was blowing in the south-west, but the force of the wind had not attained to that of a fresh gale (force eight of Beaufort notation) in any part of the United Kingdom, although the wind, which on the previous day had been north-easterly, was now everywhere southerly. The self-recording barograph at Valencia shows that the lowest barometer occurred at 7 p.m. I6th, and between eight and nine in the evening the wind shifted from east by south to west-south-west. The central area of the storm was not far distant from Valencia at this time, and during the succeeding night it traversed Ireland in a direction from south-west to north-east, the whole storm-system progressing at the rate of of about twenty-five geographical miles an hour. By the morning of November I7 the heart of the storm had reached the west of Scotland, the lowest barometer reading reported to the Meteorological Office being 28.53 ins. at Ardrossan. Strong gales had blown during the preceding night in the north and west, and the force of a gale was still reported at many places on our coasts, while the wind had shifted to the north-westward over Ireland. The weather information for the evening of the 17 th shows that the storm had continued its course to the north-eastward, and at six o'clock the centre of the disturbance was not far from Wick, where the barometer was 28.57 ins. The north-westerly gale was still blowing over the western portion of the kingdom, but there was a decided lull in the strength of the wind in the east and south-east of England. It was shortly after this time that the greatest violence of the storm burst suddenly over the northern part of the country, and at Deerness, in the Orkneys, the wind at 6 p.m. shifted suddenly from east by north to north by east.

The subsequent track of the storm had a most important influence on the increased violence of the wind, and there seems no reason to suppose that if the disturbance had continued its north-easterly track the gales experienced would have been at all unusual. A very important change in the distribution of atmospheric pressure was in progress over Western Europe, and the change of track and subsequent violence is clearly to be traced to these barometer changes. The anticyclone over Central Russia, which had given way for the small disturbance which first traversed the southern portion of England on the I4th and 15 th, was now reasserting itself, and this formed a most effectual barrier to the further north-easterly progress of the storm. In addition to 
this, the "ridge" of high barometer which was following the storm was of a very pronounced character, and caused a rapid recovery of pressure in the rear of the disturbance. As the result of these two regions of high barometer, or anticyclones, between which the storm system, or cyclone, was situated, the central area of the storm was brought to bay, and abruptly struck out on a path to the south-eastward, in which direction there was the least resistance to its progress. This halting and indecision and abrupt change of path on the part of the storm area caused the high pressure system in the rear to considerably gain on it, with the result that exceptionally steep gradients were caused for northerly gales, which continued to blow for a period of two or three days over our islands.

The diagram showing the barometer and wind for 8 a.m. November 18 , indicates a decided change in the course of the disturbance, and at that hour the lowest
November I6, ro a.m., to November 20, 9 p.m. - $4 \frac{1}{2}$ Days.

\begin{tabular}{|c|c|c|c|c|c|}
\hline \multirow{2}{*}{ Station. } & \multicolumn{3}{|c|}{ Maximum velocity. } & \multirow{2}{*}{ 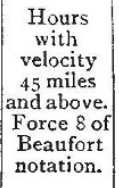 } & \multirow{2}{*}{$\begin{array}{l}\text { Mean } \\
\text { hourly } \\
\text { velocity } \\
\text { for } \\
4 \frac{1}{2} \text { days. }\end{array}$} \\
\hline & Miles. & Direction. & Rate. & & \\
\hline Valencia $\ldots \quad \ldots$ & 60 & $\begin{array}{l}\text { N.N.W. } \\
\text { N.W. }\end{array}$ & I8 4 a.m. & $3^{\mathrm{I}}$ & 33 \\
\hline Scilly $\quad \ldots \quad \ldots$ & 66 & N.W.b.N. & $18\left\{\begin{array}{l}2 \text { a.m. } \\
6 \text { a.m. }\end{array}\right.$ & 41 & $4 \mathrm{I}$. \\
\hline $\begin{array}{l}\text { Holyhead } \\
\text { Orkney } \ldots\end{array}$ & $\begin{array}{l}89 \\
96\end{array}$ & $\begin{array}{l}\text { N.b.w. } \\
\text { N. }\end{array}$ & $\begin{array}{rrr}18 & \text { Ir a a.m. } \\
\text { I7 } & 9 \text { p.m. }\end{array}$ & $\begin{array}{l}76 \\
40\end{array}$ & $\begin{array}{l}54 \\
39\end{array}$ \\
\hline North Shields & 69 & N. & I8 $\left\{\begin{aligned} 9 & \text { a.m. } \\
\text { ro } & \text { a.m. }\end{aligned}\right.$ & 16 & 33 \\
\hline $\begin{array}{lll}\text { Yarmouth } & \ldots \\
\text { Kew } \ldots & \ldots & \ldots\end{array}$ & $\begin{array}{l}64 \\
3^{3}\end{array}$ & $\begin{array}{l}\text { N.E.b.N. } \\
\text { N.N.W. }\end{array}$ & $\begin{array}{rr}20 & 5 \mathrm{a} \cdot \mathrm{m} \\
18 & 7 \mathrm{p} \cdot \mathrm{m}\end{array}$ & $\begin{array}{r}3 \mathrm{I} \\
0\end{array}$ & $\begin{array}{l}33 \\
23\end{array}$ \\
\hline
\end{tabular}

BAROMETER AND WIND.

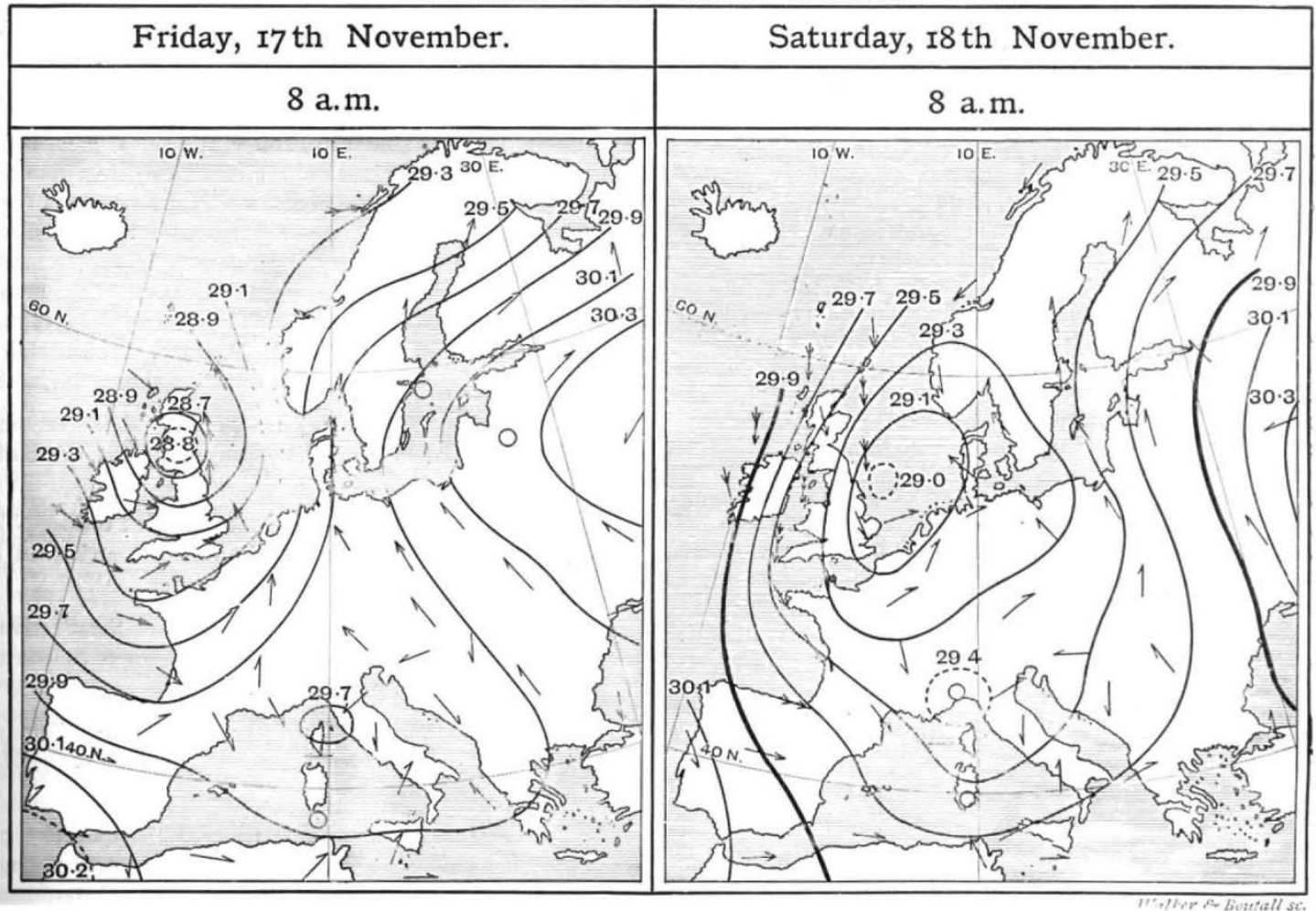

Diagram to illustrate the storm during the period of its greatest violence on November 17 and 18 . The barometer is expressed by isobars, the pressure corresponding to each line being given in inches and tenths. The winds are shown by arrows which are drawn flying with the wind. $\odot=a$ calm

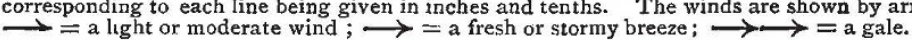

barometer was 28.99 inches at Spurn Head, the centre of the disturbance being situated about 50 miles to the east of Scarborough, and travelling south-eastwards down our east coast. On the 19th the disturbance had reached Cuxhaven, where the barometer was reading $29^{\circ} 10$ inches, and on the 2oth it was passing away over central Europe, but gales were still blowing in the south-east of England and in parts of the North Sea.

The following table shows the strength of the wind in miles per hour as recorded by the velocity anemometers under the supervision of the Meteorological Council, who have kindly allowed access to the anemographs and tabulations:-
The factor 3 is used with all the anemometers for obtaining the velocity of the wind.

The hourly velocity at Orkney was 90 miles or above for 5 consecutive hours--from 9 p.m. I th, to I a.m. I 8 th-and both this and the maximum velocity of 96 miles in the hour is in excess of any previous record in this country, the highest velocity in the hour previously recorded being 9 I miles at Fleetwood in a gale which occurred on May 20, I887. At Holyhead the wind was 65 miles or above, force Io of Beaufort's notation, for 31 hours, and was 85 miles an hour or above for 4 hours.

The storm appears to have originated on November 7 to the east of the Florida coast, near the Bahamas, and

NO. I 265 , VOL. 49] 
it can be tracked completely across the Atlantic to our islands, and eventually to central Europe on November 20. Several vessels keeping logs for the Meteorological Office, with standard instruments on board, have recorded observations on the storm during its passage across the Atlantic, and the Cunard steamship Lucania was under the influence of the disturbance during the whole of her passage from America to England. During the storm no fewer than 335 lives were reported as lost on or near our own coasts, this number being the result of reports received during the four weeks subsequent to the storm. CHAS. HARDING.

\section{PAUL HENRI FISCHER.}

THE Museum of Natural History of Paris has suffered a great loss in the person of Dr. Paul Henri Fischer, the well-known zoologist and palæontologist, who died on November 29, after a long and painful illness. Born at Paris, on July 7, 1835, he received his early classical and medical education at Bordeaux. $\mathrm{He}$ became Interne des Hôpitaux of Paris in 1859 , and obtained his degree of Doctor of Medicine in 1863 . The study of medicine did not prevent him from devoting himself also to that of the natural sciences; for in $186 \mathrm{I}$ he entered as Demonstrator in the Laboratory of Palæontology of the Museum of Paris, under the direction of M. d'Archiac. His researches chiefly concerned the living and fossil mollusca, and from 1856 he edited the Journal de Conchyliologie in collaboration with M. Crosse. From the position of Demonstrator he rose to be aide-naturaliste (assistant), and studied with great success the marine animals of the coasts of France, their geographical and bathymetric distribution. He indicated the depths at which a large number of foraminifera, ccelenterata, echinodemata, mollusca, bryozoa, \&.c. can be collected on the coasts of the west of France. In collaboration with the Marquis de Folin he undertook the study of the animals dredged in the extremely interesting region of the Gulf of Gascony, to which the name "Fosse du Cap Breton" has been given. The two savants discovered a large number of forms hitherto unknown, and many which recalled species only known in the fossil cundition. With M. Delesse he made researches on the submarine sediments of the French shores. He was elected member of the Commission of Dredging, and took part from I880 to I883, on board the Travailleur and the Talisman, in the celebrated expeditions directed by Prof. Milne Edwards. In the course of these expeditions he noted the enormous extension of a cold fauna characterised by boreal and arctic species, and reaching as far as Senegal, where it lives beneath a superficial fauna with intertropical characters. Among the writings of Dr. Fischer, which number not less than 300 titles, including books, pamphlets and memoirs, we may cite: "Palcontologie de l'Asie mineure" (in collaboration with MM. d'Archiac and de Verneuil); "Mollusques de Mexique et de l'Amerique Centrale"; "Species général et iconographie des coquilles vivantes"; "Animaux fossiles du Mont Léberon" (in collaboration with MM. Gaudry and Tournouer); "Paléontologie de l'île de Rhodes "; "Cétacés du Sud-Ouest de la France "; " Catalogue et distribution géographique des mollusques terrestres, fluviatiles et marins d'une partie de l'Indo-Chine ; "Sur les caractères de la faune conchyliologique terrestre et fluviatile récemment éteinte du Sahara"; "Sur la faune conchyliologique de l'île d'Haïnan"; numerous memoirs on the malacological fauna of Lord Hudson Island (Pacific Ocean), of Cambodge, of the islands of the Caledonian Archipelago, of Aleutian islands, of the Bay of Suez, \&c. In collaboration with M. E. L. Bouvier he published papers on the anatomical peculiarities of certain groups of molluscs. Finally, he wrote a remarkable treatise on conchology which has become classical ("Manuel de Conchyliologie et de paléontologie conchyliologique ou histoire naturelle des mollusques vivants et fossiles, suivi d'un appendice sur les Brachiopodes par (Ehlert." In this manual the author showed that the classification of molluscs ought to be based not alone on the form of the shell, but primarily on the anatomical characters.

Dr. Fischer was Chevalier de la Légion d'Honneur and Officier de l'Instruction publique. He obtained several prizes at the Paris Academy of Sciences, and had been President of the Zoological and Geological Societies of France. He possessed deep erudition, was a charming conversationalist, and after having treated a subject belonging to the domain of the natural sciences or of medicine, he was far from embarrassed if he had to discuss philosophy, literature, or æsthetics. The death of this savant, who was as affable as he was modest, has been a cause for general regret and for deep mourning among his large circle of friends.

EDMOND BORDAGE.

\section{NOTES.}

The Academy of Natural Sciences of Philadelphia has awarded the Hayden Medal to Prof. Huxley. The medal is of bronze, and, with the balance of the interest arising from a sum of 2,500 dollars given to the Academy by the widow of the late Prof. F. V. Hayden, is awarded annually " for the best publication, exploration, discovery, or research in the sciences of geology and palæontology, or in such particular branches thereof as may be designated." The recipient in 1892 was Prof. E. Suess, and in I891, Prof. E. D. Cope. Prof. J. Hall had the distinction of receiving the first award of the medal in 1890 .

Sir Henry Roscoe has been appointed to the vacancy in the Senate of London University caused by the death of Sir William Smitb.

AN Elliott Cresson Medal has been awarded to Mr. Nikola Tesla, by the Franklin Institute, for his researches in high frequency phenomena.

M. GuYon has been elected a member of the Section de Géographie et Navigation of the Paris Academy of Sciences, in the place of the late Admiral Paris.

DR. E. Zacharius, Extraordinary Professor of Botany in Strasburg University, has been appointed Director of the Hamburg Botanical Gardens.

DR. J. K. HASSKarl, who introduced the cinchona plant into Java, died at Cleves, Germany, on January 5, at the age of eighty-two. In 1852 he was sent by the Dutch Government to South America to collect cinchona seeds and plants. He did not confine himself to collecting Calisaya, but gathered seeds and plants of other varieties, some of which were new. In I854 he successfully carried about four hundred Calisaya plants to Java, but two years later he left Java, owing to differences between Dr. Junghuhn and himself on many vital principles of the system of cinchona culture. It is a singular fact, remarks the Chemist and Druggist, that the most valuable of all cinchonas, the Ledgeriana variety, was not introduced into the Indies by any of the collectors specially appointed by the British or Dutch Governments, but by a private trader in South America, the late Mr. Ledger.

THE annual general meeting of the Geologists' Association will be held at University College, London, on February 2. After the reading of the report and election of officers for the ensuing year, the President will deliver an address on "Geology in the Field and in the Study." 